\title{
A LONGITUDINAL ANALYSIS ON THE MICRO-FOUNDATIONS OF STRATEGIC MANAGEMENT: WHERE ARE MICRO- FOUNDATIONS GOING?
}

Mehmet BAĞIŞ ${ }^{1}$

\section{ABSTRACT}

Keywords:

Strategic Management

Micro-foundations

Theoretical Foundations

Research Topics

Qualitative Content Analysis

JEL Codes:

M19

\author{
Received Date (Başvuru Tarihi): \\ $26 / 03 / 2020$ \\ Accepted Date (Kabul Tarihi): \\ $10 / 05 / 2020$ \\ Published Date (Yayın Tarihi): \\ $25 / 06 / 2020$
}

The aim of this study was to investigate the theories and research topics that guided the micro-foundations of the strategic management discipline between the years 2000-2020 and to make suggestions about the future of micro-foundations research. In the study, 122 articles were analyzed by the structured literature review method. In the research, qualitative content analyses were used and an inductive analysis was performed. As a result of the analyses, theories were classified based on the disciplines. In research topics, sub-categories were determined by bringing together the similar topics. Then, research topics are coded from subcategories to basic categories. The findings indicated that the micro-foundations of strategic management were dominated by behavioral theory of the firm, evolutionary theories of economic change and Coleman's social theory between the years 2000-2010. In addition to these three theories, the effects of actor-social network theories, theory of practice, behavioral decision theory, goal framing theory, organizational learning theory, upper echelon theory and transactive memory system were present between the years 2011-2020. According to the findings, variables such as cognition, motivation, human resources management, human capital, managers and individual variables were investigated in the micro-foundations of macro-strategic phenomena at the levels of capabilities, organization and network between the years 2000-2010. Between the years 2011-2020, macro-phenomena such as context, acquisition and mergers were also included in micro-foundations research, in addition to macro-strategic phenomena in the previous period. The topics such as psychology and entrepreneurship were included within the scope of micro-phenomena discussed in the studies in the previous period between the years 2011-2020.

\footnotetext{
${ }^{1}$ Dr. Öğretim Üyesi, Sakarya Uygulamalı Bilimler Üniversitesi, Uygulamalı Bilimler Fakültesi, mehmetbagis@subu.edu.tr, https://orcid.org/0000-0002-3392-3376
} 


\section{STRATEJİK YÖNETIMİN MİKRO TEMELLERİ ÜZERİNE BOYLAMSAL BİR ANALIZ: MİKRO TEMELLER NEREYE GİDIYOR?}

$\ddot{O Z Z}$

\author{
Anahtar Kelimeler: \\ Stratejik Yönetim \\ Mikro Temeller \\ Teorik Temeller \\ Araştırma Konular \\ Nitel İçerik Analizi
}

JEL Kodlari:

M19
Bu araştırmanın amacı 2000-2020 yıllar arasında stratejik yönetim disiplininin mikro temellerine yön veren teorileri ve araştırma konularm inceleyerek, mikro temeller araştırmalarının geleceğiyle ilgili önerilerde bulunmaktır. Çalışmada yapılandırılmış literatür incelemesi yöntemiyle 122 makale incelenmiştir. Araşstırmada nitel içerik analizi kullanılmış ve tümevarımsal bir analiz yapılmıştır. Analizler sonucunda teoriler disiplinler temelinde sinıflandırlmıştır. Araştırma konular ise alt kategorilerden temel kategorilere doğru kodlanmıştır. Bulgular 2000-2010 yillar arasında stratejik yönetimin mikro temellerine firma davranışı teorisi, evrimsel ekonomi teorisi ve Coleman'in sosyal teorisinin hâkim olduğunu göstermektedir. 2011-2020 yılları arasında ise alanda bu üç teoriye ek olarak aktör/sosyal ağ teorileri, uygulama teorisi, davranışsal karar teorisi, amaç çerçeveleme teorisi, örgütsel öğrenme teorisi, üst yönetim teorisi ve geçişken bellek sistemi teorisinin etkileri bulunmaktadır. Bulgulara göre 2000-2010 yıllar arasında yetenekler, örgütler ve ağlar gibi makro stratejik olgularn mikro temelinde biliş, motivasyon, insan kaynaklarn yönetimi, insan sermayesi ve yöneticiler gibi değişkenler araştıılmıştır. 2011-2020 yılları arasında ise bir önceki dönemdeki makro stratejik olgularn yanında bağlam, satınalma ve birleşmeler gibi makro olgular da mikro temeller araştırmalarına dâhil edilmiştir. 2011-2020 yilları arasinda bir önceki dönemde araştırmalara konu olan mikro olguların kapsamına ise psikoloji ve girişimcilik gibi konular girmiştir. 


\section{INTRODUCTION}

The field of strategic management, which attempts to explain the reasons for performance and success differences between the firms, has addressed strategic phenomenon with different approaches and views since the 1980s. These approaches and views include positioning school (Porter, 1980; 1981), resource based view (Barney, 1991), dynamic capabilities (Teece and Pisano, 1994; Teece et al., 1997), knowledge based view (Grant, 1996a; 1996b), strategy as a practice (Whittington, 1996), attention based view (Ocasio, 1997), relational view (Dyer and Singh, 1998; Lavie, 2006) and institution based view (Peng, 2002; Peng et al., 2009).

The approaches and views developed in the field have explained the strategic phenomenon mostly at the macro-analysis level. However, there are also scientists who included micro-analysis levels in their studies. Hambrick and Mason (1984: 198) emphasized micro-foundations by analyzing the cognitive and upper echelon characteristics of the senior management team. In another study, Grant (1996b: 112) called for giving up the concept of organizational knowledge by touching on the role of the individual in knowledge creation and storage. Coff (1997: 374; 1999: 119) examined the concept of firm-level competitive advantage and indicated that the concept of competitive advantage could be reduced to individual actions. Finkelstein et al. (1996: 4) addressed the concept of strategic leadership in their study. Although those studies emphasized micro-analysis levels, they could not create an accumulated literature on micro-foundations in the field.

This situation caused strategic management scientists to create a new research trend focusing on micro-foundations in the 2000s. The micro-foundations literature focuses on the effects of strategic phenomena (Felin and Foss, 2005) on capabilities, firm and firm performance resulting from individuals and the relationships between individuals. In other words, micro-foundations research combines the topics at the micro and macro analysis levels (Barney and Felin, 2013). This trend was created based on the inadequacies in the explanation of macro-level (routines/capabilities and firm) strategic phenomena (Abell et al., 2008). The studies at the macro-analysis level conceptualize organizations as routines and a pool of capabilities (Kogut and Zander, 
1992; Nelson and Winter, 1982). According to this conceptualization, routines and capabilities lead to firm-level behaviors and consequences. These consequences and behaviors are also analyzed through firm-level macro-variables. These firm-level explanations do not fully explain how capabilities are formed and how individuals and relationships between individuals affect the firm performance and behavior (Abell et al., 2008). Therefore, variables at micro-analysis levels such as cognition and motivation have been discussed in strategic management studies in order to find answers to these problems.

The evaluations related to this literature that emerged in the field of strategic management in the 2000s were performed by different scientists. In previous studies, why micro-foundations research was needed (Foss, 2011), what micro-foundations were (Barney and Felin, 2013) and a general evaluation of the literature (Foss and Linder, 2019; Felin et al., 2015; Molina-Azorín, 2014) were discussed. In those studies, Foss (2011) examined why micro-foundations were needed in the resource-based view and mentioned where to look for the development of micro-foundations. Barney and Felin (2013), who opened what the right and wrongs about micro-foundations could be for discussion, touched on four topics related to the literature. According to the authors, the literature does not only consist of psychology, human resources and micro organizational behavior, and the concepts borrowed from different disciplines. Furthermore, studies on micro-foundations do not lead to infinite regress, and the topics at the macro-analysis level should also be included in the discussions. In another study, Molina-Azorín (2014) examined the studies in the literature and revealed that strategic management studies in general and the resource-based view in particular evolved towards the studies combining macro and micro analysis levels. In another study, Helfat and Martin (2015) attempted to explore the micro-foundations of dynamic managerial capabilities between the years 1980 and 2013. Finally, Felin et al. (2015) briefly touched on the micro-foundations movement in the disciplines of economics and sociology and evaluated the origins, history and different forms of the micro-foundations movement and the difficulties faced.

None of the studies related to the literature we have reviewed so far did not fully explain the question of what the theories and research trends that guide the 
micro-foundations literature are and how they evolved. Therefore, this study differs from other studies examining the micro-foundations literature by systematically and longitudinally analyzing the theories and research topics contributing to the microfoundations of strategic management between the years 2000-2020. The aim of the study can be collected under two titles. 1- To reveal the change in the literature by analyzing the theories and research topics contributing to the micro-foundations of strategic management between the years 2000-2020. 2- To present theories and research proposals which have never been studied in the micro-foundations literature and have the potential to contribute to the literature.

In this context, this study sought an answer to the question of "how did the theories and research topics that guided the micro-foundations of strategic management change between the years 2000-2020?" Within the framework of this research question, the contribution of the study can be explained under two titles. Firstly, which theories and research trends dominated the micro-foundations of strategic management was identified. Secondly, suggestions were made to enable the micro-foundations literature to make new expansions. The next sections of the research consist of three parts. The methodology of the research was revealed in the second part and the findings were revealed in the third part. Finally, in the fourth part, the research was completed with conclusions and discussions.

\section{METHODOLOGY}

The qualitative approach of a structured literature review (Zupic and Čater, 2014: 2) was used to determine the studies to be analyzed. This method enabled the studies on the micro-foundations literature to be structured by the author of the study. Although structured literature reviews are criticized for being based on the subjective evaluations of the author (Zupic and Čater, 2014), they allow for the in-depth analysis of the studies examined and understanding the context of the studies (Raghuram et al., 2010). This method has been frequently used in reviewing the studies in the strategic management literature (Barney et al., 2011; Felin et al., 2015; Molina-Azorín, 2014). 
The journals indexed in the Web of Science Social Science Citation Index (SSCI) were preferred during the literature structuring process. Web of Science was selected since it is the most preferred database by management scientists in structured literature reviews and bibliometric studies (Zupic and Čater, 2014). Journals such as Strategic Management Journal, Journal of Management Studies, Organization Science, Academy of Management Review, Journal of Management, Strategic Organization and Academy of Management Perspectives were reviewed in this database. These journals were preferred since they have high impact and standards in the studies on strategic management. However, the studies that contributed to the micro-foundations of strategic management with tracing method and were published in different journals from these journals were also included in the review, which was due to the fact that the studies on micro-foundations were spread to a large number of journals. The publication numbers and rates obtained from the journals are presented in Table 1 below.

Table 1. Journals, Publication Numbers and Rates

\begin{tabular}{|l|c|c|}
\hline \multicolumn{1}{|c|}{ Journals } & Publication Number & Publication Rate \\
\hline Strategic Management Journal & 30 & 24,59 \\
\hline Journal of Management Studies & 19 & 15,57 \\
\hline Organization Science & 12 & 9,84 \\
\hline Academy of Management Review & 6 & 4,92 \\
\hline Journal of Management & 8 & 6,56 \\
\hline Strategic Organization & 6 & 4,92 \\
\hline Academy of Management Perspectives & 5 & 4,1 \\
\hline Journal of Institutional Economics & 4 & 3,28 \\
\hline Academy of Management Annals & 4 & 3,28 \\
\hline Erkenntnis & 2 & 1,64 \\
\hline European Management Review & 2 & 1,64 \\
\hline Human Resource Management & 2 & 1,64 \\
\hline Research Methodology in Strategy and & 2 & 1,64 \\
Management & 2 & 1,64 \\
\hline Industrial and Corporate Change & 2 & 1,64 \\
\hline Managerial and Decision Economics & 16 & 13,11 \\
\hline Others & $\mathbf{1 2 2}$ & $\mathbf{1 0 0}$ \\
\hline
\end{tabular}

Source: developed by the author

Theoretical and empirical articles were included in the studies to be evaluated. The studies were reviewed with a historical grouping. Groupings were made between the years 2000-2010 and 2011-2020. The purpose of this classification is to be able to see the historical evolution and change patterns of the literature over a decade (Üsdiken and Wasti, 2002: 18-20). The qualitative content analysis was used in the study. Firstly, 
the studies were listed historically or chronologically. Then, the articles were read. The data collected from the articles were divided into two titles as the theories and research topics used in the articles. In the first stage, theories were given with a distinction in the form of economics, sociology, psychology and other disciplines. This distinction was made based on the findings obtained from the data. Thus, the effects of the theories that contributed to the micro-foundations of strategic management between the years 2000-2010 and 2011-2020 could be seen. In the second stage, research topics were coded. Coding was performed inductively. In this stage, firstly, similar topics were brought together and sub-categories were determined. Then, coding was made from subcategories to main categories (Bowen, 2009; Flick, 2018; Miles and Huberman, 1994; Schreier, 2012; Strauss, 1987)

\section{FINDINGS}

The findings obtained as a result of the analyses are presented in tables. At first, 122 studies included in the analyses and the authors of the studies are presented in Table 2 in a historical order. In Table 2, it appears that 34 studies between 2000-2010 and 88 studies between 2011-2020 were related to the micro-foundations of strategic management. Authors such as Adner and Helfat (2003), Lippman and Rumelt (2003a; 2003b), Foss (2003; 2005), Pozzebon (2004), Felin and Foss (2005) and Gavetti (2005) were the authors who first touched on the micro-foundations of strategic management in the first half of the 2000s. In those studies, Adner and Helfat (2003: 1020) examined the concepts of managerial human capital, managerial social capital and managerial cognition and developed the concept of dynamic managerial capabilities. In their study, Lippman and Rumelt (2003a; 2003b) associated resource-based view and game theory. Foss $(2003 ; 2005)$, another one of the authors, brought the concepts such as bounded rationality, tacit knowledge, reductionism, transaction costs, property rights, methodological individualism and methodological collectivism to the foundation of organizational capabilities. Another author, Pozzebon (2004: 247) discussed the topic within the framework of structuration theory based on the structure-action debate. In the last study in the first half of the 2000s, Felin and Foss (2005) were the pioneers of the micro-foundations research trend based on the question 
Table 2. Articles with Content Analysis

\begin{tabular}{|c|c|c|c|c|c|}
\hline Authors & Date & Authors & Date & Authors & Date \\
\hline Adner and Helfat & 2003 & Bingham and Eisenhardt & 2011 & Hansen and Alewell & 2013 \\
\hline Helfat and Peteraf & 2003 & Rerup and Feldman & 2011 & Baer et al. & 2013 \\
\hline Lippman and Rumelt & $2003 a$ & Gooderham et al. & 2011 & Greve & 2013 \\
\hline Lippman and Rumelt & $2003 b$ & Salvato and Rerup & 2011 & Kemper et al. & 2013 \\
\hline Foss & 2003 & Winter & 2011 & Loch et al. & 2013 \\
\hline Pozzebon & 2004 & Hodgson and Knudsen & 2011 & Bridoux and Stoelhorst & 2014 \\
\hline Felin and Foss & 2005 & Barney et al. & 2011 & Helfat and Peteraf & 2015 \\
\hline Gavetti & 2005 & Lewin et al. & 2011 & Miller et al. & 2014 \\
\hline Foss & 2005 & Reinholt et al. & 2011 & Molina-Azorín & 2014 \\
\hline Felin and Foss & 2006 & Floyd and Sputtek & 2011 & Laureiro-Martinez & 2014 \\
\hline Teece & 2007 & Powell et al. & 2011 & Kleinbaum and Stuart & 2014 \\
\hline Felin and Hesterly & 2007 & Levinthal & 2011 & Ployhart and Hale & 2014 \\
\hline Foss & 2007 & Argote and Ren & 2012 & Grigoriou and Rothaermel & 2014 \\
\hline Gottschalg and Zollo & 2007 & Felin & 2012 & Morris et al. & 2014 \\
\hline Abell et al. & 2008 & Felin and Foss & 2012 & Rogan and Mors & 2014 \\
\hline Nickerson and Zenger & 2008 & Felin et al. & 2012 & Kor and Mesko & 2014 \\
\hline Felin and Foss & 2009 & Foss et al. & 2012 & Felin et al. & 2015 \\
\hline Felin et al. & 2009 & Hodgson & 2012 & Maclean et al. & 2015 \\
\hline Foss & 2009 & Winter & 2012 & Helfat and Martin & 2015 \\
\hline Laamanen and Wallin & 2009 & Cohen & 2012 & Aguinis and Molina-Azorín & 2015 \\
\hline Salvato & 2009 & Teece & 2012 & Dai et al. & 2016 \\
\hline Abell et al. & 2010 & Bapuji et al. & 2012 & Bridoux et al. & 2016 \\
\hline Vromen & 2010 & Cacciatori & 2012 & Foss and Pedersen & 2016 \\
\hline Foss & 2010 & Pentland et al. & 2012 & Martin et al. & 2017 \\
\hline Foss et al. & 2010 & Turner and Fern & 2012 & Aggarwal et al. & 2017 \\
\hline Eisenhardt et al. & 2010 & Miller et al. & 2012 & Arndt and Pierce & 2017 \\
\hline Litchfield and Gentry & 2010 & Minbaeva et al. & 2012 & Yao and Chang & 2017 \\
\hline Volberda et al. & 2010 & Obloj and Sengul & 2012 & Distel & 2017 \\
\hline Lichtenthaler et al. & 2010 & Rodenbach and Brttel & 2012 & Kauppila et al. & 2017 \\
\hline Cabiddu & 2010 & Mäkelä et al. & 2012 & Levine et al. & 2017 \\
\hline Aime et al. & 2010 & Wang and Wong & 2012 & Menon & 2017 \\
\hline Harrison et al. & 2010 & Paruchiri and Eisenman & 2012 & Mahringer and Renzl & 2018 \\
\hline Campbell et al. & 2010 & Turner and Makhija & 2012 & Bagis & 2018 \\
\hline Laureiro-Martinez et al. & 2010 & Mollick & 2012 & Huy and Zott & 2018 \\
\hline Felin and Foss & 2011 & Gavetti & 2012 & Jalonen and Vaara & 2018 \\
\hline Foss & 2011 & Ahuja et al. & 2012 & Salvato and Vassolo & 2018 \\
\hline Garbuio et al. & 2011 & 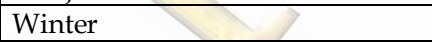 & 2013 & Nayak et al. & 2019 \\
\hline Hodgkinson and Healey & 2011 & Barney and Felin & 2013 & Doyle et al. & 2019 \\
\hline Lindenberg and Foss & 2011 & Friesl and Larty & 2013 & Suddaby et al. & 2020 \\
\hline Coff and Kryscynski & 2011 & Foss and Lindenberg & 2013 & Wernerfelt & 2020 \\
\hline Ployhart and Moliterno & 2011 & Eggers and Kaplan & 2013 & & \\
\hline
\end{tabular}

Source: developed by the author

"What are the individual level premises and resources of organizational capabilities?"

As it can be seen from the studies in the first half of the 2000s, micro-foundations research trend has an eclectic character like strategic management research. In other words, micro-foundations consist of a combination of the concepts of economics, sociology and psychology. These authors' first studies on micro-foundations constituted the basis of the research trend that would develop as micro-foundations in the field in the later years. 
After the first evaluations made so far on the findings, the disciplines and theories that contributed to the micro-foundations of strategic management between 2000-2010 and 2011-2020 are presented in Table 3 below. An evaluation to be made on both periods in Table 3 reveals the effects of the theories in economics, sociology and psychology disciplines on micro-foundations literature. The findings indicate that the theories such as A behavioral theory of the firm (Cyert and March, 1963), human capital theory (Becker, 1964) and evolutionary theories of economic change (Nelson and Sidney, 1982) more effective on the micro-foundations literature than other theories between the years 2000-2010. The effects of these theories increased in the time period between the years 2011-2020 compared to the previous period, and also, their effects were higher compared to other theories between the years 2011-2020. Among those theories, a behavioral theory of the firm contributed to the field with the concepts of routines, standardized business process and decision making. The theory reveals the behavioral dimension of the micro-foundations literature. While human capital theory focused on the education of human capital, the evolutionary theories of economic change contributed to the micro-foundations field with the concepts of individual skills, tacit knowledge and organizational capabilities.

As can be seen from Table 3, Coleman's social theory (Coleman, 1990) from sociology discipline was more effective on micro-foundations in both periods. Coleman's social theory contributed to the micro-foundations field with the concepts of methodological individualism and methodological collectivism. While social phenomena should be explained in terms of individuals and the relationships between individuals according to methodological individualism, social phenomena should be examined in terms of institutions, social structures and cultures according to methodological collectivism (Hodgson, 2012: 2-3). According to the findings in Table 3, the theories without much effect such as actor-network theory/social network theory, theories of practice and structuration theory/social theory between the years 2000-2010 on the basis of sociology discipline had intensive effects on the microfoundations of strategic management between the years 2011-2020. Among those theories, network theories focused on the contributions of interpersonal relationships 
to the micro-foundations literature, however, the structuration theory introduced the concepts of ostensive and performative routines to the micro-foundations literature.

Table 3. Disciplines and Theories Contributing to Micro-foundations

\begin{tabular}{|c|c|c|c|}
\hline & Theories & $2000-2010$ & 2011-2020 \\
\hline \multirow{9}{*}{ ᄅ્ટّ } & $\begin{array}{l}\text { Economy, experimental } \\
\text { economics }\end{array}$ & Felin et al. 2009 & Foss, 2011 \\
\hline & $\begin{array}{l}\text { A behavioral theory of the } \\
\text { firm }\end{array}$ & $\begin{array}{l}\text { Adner and Helfat, 2003; } \\
\text { Gavetti, 2005; Felin and Foss, } \\
\text { 2009; Foss, 2009; Laureiro- } \\
\text { Martinez et al. 2010; } \\
\text { Lichtenthaler et al. } 2010\end{array}$ & $\begin{array}{l}\text { Felin and Foss, 2011; Hodgson and Knudsen, 2011; } \\
\text { Lewin et al. 2011; Turner and Fern, 2012; Felin et al. } \\
\text { 2012; Gavetti, 2012; Barney and Felin, 2013; Martin et al. } \\
\text { 2017; Arndt and Pierce, 2017; Levine et al. } 2017\end{array}$ \\
\hline & Human capital theory & Campbell et al. 2010 & $\begin{array}{l}\text { Ployhart and Moliterno, 2011; Coff and Kryscynski, } \\
\text { 2011; Barney and Felin, 2013; Ployhart and Hale, } 2014\end{array}$ \\
\hline & $\begin{array}{l}\text { Evolutionary theories of } \\
\text { economic change }\end{array}$ & $\begin{array}{l}\text { Helfat and Peteraf, 2003; Foss, } \\
\text { 2003; Gavetti, 2005; Teece, } \\
\text { 2007; Felin and Foss, 2009; } \\
\text { Foss, } 2009\end{array}$ & $\begin{array}{l}\text { Hodgson and Knudsen, 2011; Lewin et al. 2011; Salvato } \\
\text { and Rerup, 2011; Cohen, 2012; Gavetti, 2012; } \\
\text { Winter,2012; Foss et al. 2012; Eggers and Kaplan, 2013; } \\
\text { Arndt and Pierce, } 2017\end{array}$ \\
\hline & Austrian School of Economics & Teece, 2007 & + \\
\hline & Game theory & $\begin{array}{l}\text { Lippman and Rumelt, 2003a } \\
\text { Lippman and Rumelt, 2003b }\end{array}$ & Levine et al. 2017; Menon, 2017 \\
\hline & Adaptation-cost theory & & Wernerfelt, 2020 \\
\hline & Transaction cost theory & Foss, 2005 & Hansen and Alewell, 2013 \\
\hline & Property rights theory & Foss, 2005 & $\infty$ \\
\hline \multirow{6}{*}{ की } & Coleman's social theory & $\begin{array}{l}\text { Felin and Foss, 2005; Felin and } \\
\text { Foss, 2006; Foss, 2007; Abell et } \\
\text { al. 2008; Foss, 2009; Abell et al. } \\
\text { 2010; Vromen, 2010 }\end{array}$ & $\begin{array}{l}\text { Felin and Foss, 2012; Minbaeva et al. 2012; Felin et al. } \\
\text { 2012; Mäkelä et al. 2012; Distel, } 2017\end{array}$ \\
\hline & $\begin{array}{l}\text { Actor-network theory/social } \\
\text { network theory }\end{array}$ & & $\begin{array}{l}\text { Salvato and Rerup, 2011; Bapuji et al. 2012; Paruchiri } \\
\text { and Eisenman, 2012; Ahuja et al. 2012; Kleinbaum and } \\
\text { Stuart, 2014; Grigoriou and Rothaermel, 2014; Rogan } \\
\text { and Mors, 2014; Kauppila et al. } 2017\end{array}$ \\
\hline & Theory of practice & & $\begin{array}{l}\text { Pentland et al. 2012; Friesl and Larty, 2013; Jalonen and } \\
\text { Vaara, 2018; Nayak et al. } 2019\end{array}$ \\
\hline & $\begin{array}{l}\text { Structuration theory/social } \\
\text { theory }\end{array}$ & $\begin{array}{l}\text { Feldman and Pentland, } 2003 \\
\text { Pozzebon, } 2004\end{array}$ & $\begin{array}{l}\text { Cacciatori, 2012; Friesl and Larty, 2013; Maclean et al. } \\
2015\end{array}$ \\
\hline & Social capital theory & +2 & Gooderham et al. 2011 \\
\hline & Social exchange theory & Nickerson and Zenger, 2008 & \\
\hline \multirow{11}{*}{ 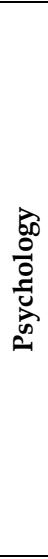 } & Behavioral decision theory & & $\begin{array}{l}\text { Garbuio et al. 2011; Hodgkinson and Healey, 2011; } \\
\text { Helfat and Peteraf, } 2015\end{array}$ \\
\hline & Prospect theory & + & Hodgkinson and Healey, 2011 \\
\hline & Goal framing theory & Fo & $\begin{array}{l}\text { Foss, 2011; Lindenberg and Foss, 2011; Foss and } \\
\text { Lindenberg, } 2013\end{array}$ \\
\hline & Upper-echelon theory & & $\begin{array}{l}\text { Floyd and Sputtek, 2011; Ployhart and Hale, 2014; } \\
\text { Salvato and Vassolo, } 2018\end{array}$ \\
\hline & Interactive creativity approach & & Bagis, 2018 \\
\hline & Motivation theory & Gottschalg and Zollo, 2007 & Reinholt et al. 2011 \\
\hline & $\begin{array}{l}\text { Organizational learning } \\
\text { theory }\end{array}$ & Aime et al. 2010 & $\begin{array}{l}\text { Bingham and Eisenhardt, 2011; Rerup and Feldman, } \\
\text { 2011; Obloj and Sengul, 2012; Yao and Chang, } 2017\end{array}$ \\
\hline & Social psychological theories & & Salvato and Vassolo, 2018 \\
\hline & Equity theory & Nickerson and Zenger, 2008 & \\
\hline & Theory of cognition & & Laureiro-Martinez, 2014 \\
\hline & Transactive memory system & & Argote and Ren, 2012; Miller et al. 2014; Dai et al. 2016 \\
\hline \multirow{5}{*}{ 离 } & History & & Suddaby et al. 2020 \\
\hline & $\begin{array}{l}\text { Evolutionary anthropology, } \\
\text { socio-evolutionary approach }\end{array}$ & & Foss, 2011; Bridoux et al. 2016 \\
\hline & Value-based framework & & Menon, 2017 \\
\hline & $\begin{array}{l}\text { Information processing } \\
\text { perspective }\end{array}$ & & Turner and Makhija, 2012 \\
\hline & Stakeholder theory & Harrison et al. 2010 & Bridoux and Stoelhorst, 2014 \\
\hline
\end{tabular}

Source: developed by the author 
Ostensive routines are routine structures that shape the actions and activities of individuals. Performative routines reveal that the elements that constitute organizational capabilities are the actors or their practices.

Another discipline that contributed to the micro-foundations of strategic management is psychology. According to the findings in Table 3, this discipline could not make its presence felt too much on the micro-foundations literature between the years 2000-2010. However, it appears that the theories such as behavioral decision theory (Simon, 1947), prospect theory (Kahneman and Tversky, 1979), goal framing theory (Locke and Latham, 2012), upper-echelon theory (Hambrick and Mason, 1984) and organizational learning theory (Crossan et al., 1995) had dominant effects on the micro-foundations field between the years 2011-2020. While behavioral decision theory and prospect theory contributed to the field by examining the decision making processes, the goal framing theory focused on how individuals' motivation status could improve the joint production motivation (Foss and Lindenberg, 2013). The upper-echelon theory contributed to the micro-foundations of strategic management by reviewing the relationships between the top management team's characteristics such as cognitive, psychological, age and education, and their strategic choices. Another theory, organizational learning supported the micro-foundations literature with the concepts of individual, group, organization and inter-organizational learning. Finally, the findings in Table 3 indicate that there are new quests to contribute to the micro-foundations of strategic management in the disciplines such as history (Suddaby et al., 2020: 1), evolutionary anthropology and socio-evolutionary approach (Bridoux et al., 2017; Foss, 2011).

After the findings evaluated and discussed so far, research topics contributing to the micro-foundations of strategic management between the years 2000-2010 in Table 4 and between the years 2011-2020 in Table 5 are presented. The topics in Table 4 and Table 5 are basically presented at two different levels of analysis. These levels of analysis can be examined under two titles: micro (individual level) and macro (capabilities, organizational and interorganizational levels) levels of analysis. This distinction is commonly used in studies examining the micro-foundations of strategic 
management (Abell et al., 2008; Bağ1ş and Hızıroğlu, 2018; Felin et al., 2012) and human resources management (Bağ1ş et al., 2019). Apart from the distinction made in both periods based on analysis levels, a title on methodological topics guiding the micro-foundations research was also opened in Table 4 and Table 5.

The findings in Table 4 indicate that individual level research topics that guided the micro-foundations research between the years 2000-2010 can be collected under five titles. These topics include cognition, motivation, human resources management/human capital, managers and individual variables. Cognitive topics include the concepts such as sensing, attention, heuristics and biases (Kahneman et al., 1982), tacit knowledge and bounded rationality. These quests for cognitive topics are the efforts to open the black box of individuals' cognitive characteristics (De Wit and Meyer, 2010: 51). As can be seen in Table 4, it appears that cognitive studies between the years 2000-2010 started with the studies of Foss (2003), Gavetti (2005) and Teece (2007). Another research topic in those years was motivation. The studies on motivation investigated the micro-foundations of joint production motivation and organizational performance within the framework of the goal framing theory (Lindenberg and Foss, 2011: 500). Human resources and human capital topics, which were among the individual level variables that gradually started to occupy the agenda of micro-foundations between the years 2000-2010, included social capital and human behavior topics. It appears that the topics related to micro-foundations were mostly aimed at understanding the topics related to micro-foundations were mostly aimed at understanding the behaviors of managers such as managerial capabilities, strategic choice, seizing and decision making.

The studies at the capabilities, organization and network levels were mostly organizational or strategic phenomena the micro-foundations of which were investigated. The concepts investigating the micro-foundations in the phenomenon of capabilities can be expressed as routines, ambidexterity and causal ambiguity, knowledge and knowledge management, respectively. The concepts attempting to investigate the micro-foundations in organizational phenomena can be listed as organizational behavior, structure, economics and firm boundaries. It appears that the studies attempting to understand the micro-foundations of network relationships at 
the inter-organizational level gradually began to be included in the field. Finally, the presence of methodological searches on micro-foundations for the years 2000-2010 was remarkable. These topics were concentrated around the concepts of methodological individualism/methodological collectivism and reductionism.

Table 4. Research Topics Guiding Micro-Foundations between the years 2000-2010

\begin{tabular}{|c|c|c|}
\hline \multirow{2}{*}{ Main Topics } & \multirow{2}{*}{ Individual Level } & $2000-2010$ \\
\hline & & Authors \\
\hline Cognition & $\begin{array}{l}\text { Cognition, cognitive psychology, sensing, } \\
\text { managerial cognition, attention allocation, attention } \\
\text { shift, attention modulation, heuristics and biases, } \\
\text { perspective-taking, ability learn, creative skills, tacit } \\
\text { knowledge, bounded rationality }\end{array}$ & $\begin{array}{l}\text { Adner and Helfat, 2003; Helfat and Peteraf, 2003; Foss, } \\
\text { 2003; Gavetti, 2005; Teece, 2007; Laamanen and Wallin, } \\
\text { 2009; Foss et al. 2010, Eisenhardt et al. 2010; Cabiddu, } \\
\text { 2010; Laureiro-Martinez et al. } 2010\end{array}$ \\
\hline Motivation & $\begin{array}{l}\text { Motivation; joint production motivation, } \\
\text { motivation management, extrinsic and intrinsic } \\
\text { motivation }\end{array}$ & Gottschalg and Zollo, 2007; Foss, 2010; Foss et al., 2010 \\
\hline $\begin{array}{l}\text { HRM/Human } \\
\text { Capital }\end{array}$ & $\begin{array}{l}\text { Human capital, human resource management } \\
\text { (HRM), human capital management, social capital, } \\
\text { human behavior }\end{array}$ & $\begin{array}{l}\text { Adner and Helfat, 2003; Nickerson and Zenger, 2008, } \\
\text { Felin et al. 2009, Campbell et al. } 2010\end{array}$ \\
\hline Managers & $\begin{array}{l}\text { Dynamic managerial capabilities, strategic choice, } \\
\text { seizing, decision making, stakeholder management }\end{array}$ & $\begin{array}{l}\text { Adner and Helfat, 2003; Pozzebon, 2004; Teece, 2007; } \\
\text { Salvato, 2009; Laureiro-Martinez et al. 2010; Harrison et } \\
\text { al. 2010 }\end{array}$ \\
\hline \multirow[t]{2}{*}{$\begin{array}{l}\text { Individual } \\
\text { variables }\end{array}$} & $\begin{array}{l}\text { Employee attitudes, employee mobility, individual } \\
\text { level heterogenity, individual skills, bargaining, } \\
\text { coalitional power }\end{array}$ & $\begin{array}{l}\text { Lippman and Rumelt, 2003a; Foss, 2003; Felin and } \\
\text { Hesterly, 2007; Lichtenthaler et al. 2010; Aime et al. } \\
2010\end{array}$ \\
\hline & $\begin{array}{c}\text { Capabilities Level } \\
\end{array}$ & $x_{1}^{2}$ \\
\hline Capabilities & $\begin{array}{l}\text { Dynamic capabilities, resource- } \\
\text { routines, ambidexterity, contex } \\
\text { ambiguity }\end{array}$ & $\begin{array}{l}\text { Lippman and Rumelt, 2003a; 2003b, Foss, 2003; 2005, } \\
\text { Felin and Foss, 2005; Gavetti, 2005; Teece, 2007, } \\
\text { Gottschalg and Zollo, 2007, Abell et al. 2008; Felin and } \\
\text { Foss, 2009; Laamanen and Wallin, 2009; Salvato, 2009; } \\
\text { Abell et al. 2010; Vromen, 2010; Foss, 2010; 2010b; } \\
\text { Eisenhardt et al. 2010; Litchfield and Gentry, 2010; } \\
\text { Volberda et al. 2010; Lichtenthaler et al. 2010; Cabiddu, } \\
\text { 2010, Aime et al. 2010, Laureiro-Martinez et al. 2010, } \\
\text { Foss et al., 2010 }\end{array}$ \\
\hline \multirow[t]{2}{*}{ Knowledge $^{2}$} & $\begin{array}{l}\text { Knowledge, knowledge governance approach, } \\
\text { knowledge management, knowledge economy, } \\
\text { knowledge based production, knowledge sharing, } \\
\text { knowledge processes, knowledge integration, } \\
\text { imperfect information }\end{array}$ & $\begin{array}{l}\text { Felin and Hesterly, 2007; Foss, 2007; Felin et al. 2009, } \\
\text { Foss, 2009; Foss, 2010; Foss et al. 2010; Litchfield and } \\
\text { Gentry, 2010; Volberda et al. 2010; Lichtenthaler et al. } \\
\text { 2010, Campbell et al. } 2010\end{array}$ \\
\hline & Organizational Level & \\
\hline \multirow[t]{2}{*}{ Organization } & $\begin{array}{l}\text { Organizational behavior, organizational search, } \\
\text { theory of the firm, firm boundaries, organizational } \\
\text { structure, hierarchy, organizational justice, } \\
\text { organizational economics (transaction costs, } \\
\text { property rights), absorptive capacity, competitive } \\
\text { advantage, performance, payments perspective; } \\
\text { rent, economic profit }\end{array}$ & $\begin{array}{l}\text { Lippman and Rumelt, 2003a; 2003b; Foss, 2003; Foss, } \\
\text { 2005; Gavetti, 2005; Foss, 2007; Nickerson and Zenger, } \\
\text { 2008; Abell et al. 2008, Litchfield and Gentry, 2010; } \\
\text { Volberda et al. 2010; Eisenhardt et al. 2010, Harrison et } \\
\text { al. 2010, Aime et al. } 2010\end{array}$ \\
\hline & Interorganizational Level & \\
\hline \multirow[t]{2}{*}{ Network } & Network & Pozzebon, 2004; Cabiddu, 2010 \\
\hline & Methodological Topics & \\
\hline Methodology & $\begin{array}{l}\text { Methodological individualism/methodological } \\
\text { collectivism, reductionism }\end{array}$ & $\begin{array}{l}\text { Foss, 2003; Felin and Foss, 2005; Felin and Foss, 2006; } \\
\text { Felin and Hesterly, 2007; Abell et al. 2008; Abell et al. } \\
\text { 2010; Foss, 2010a; Vromen, } 2010\end{array}$ \\
\hline
\end{tabular}

Source: developed by the author

\footnotetext{
${ }^{2}$ The subject of knowledge, individual, capabilities and firm were analyzed.
} 
An evaluation to be made between the years 2011-2020 over Table 5 reveals an increase in studies on the micro-foundations of strategic management. This finding supports 88 studies between the years 2011-2020 in response to 34 studies between the years 2000-2010 presented in Table 2. Another finding obtained from Table 5 indicates that the variables from the fields such as psychology, behavioral strategy and entrepreneurship between the years 2011-2020, in addition to the topics such as cognition, motivation, HRM/human capital between the years 2000-2010, were introduced to the micro-foundations field.

It appears that the scope of cognitive topics between the years 2011-2020 was extended compared to the years 2000-2010. In particular, it appears the concepts such as perception, problem solving and reasoning, language and communication, cognitive capabilities (Helfat and Peteraf, 2015) sensemaking, intuition, judgment, perspective taking, strategic mental models, cognitive neuroscience and cognitive frames dominated the micro-foundations literature. There was a significant difference in motivational topics that contributed to the micro-foundations compared to the years 2000-2010. Based on the evaluation made over Table 5, it was determined that motivational processes, heterogeneous human motives, incentives, joint production motivation, motivational mechanisms, recognition based reward structure and motivational micro-foundations (Bridoux et al., 2017) guided the years 2011-2020.

Another research topic occupying the micro-foundations of strategic management between the years 2011-2020 was the search for psychological foundations of strategy (Hodgkinson and Healey, 2011; Powell et al., 2011). It appears that the topics such as Dewey's psychology, the role of habit, contemporary psychology, social psychology, emotion regulation, emotional dynamics, behavioral strategy, behavioral economics (Thaler and Sunstein, 2009), behavioral learning, rational choice and behavioral psychology were intertwined in these searches. Another concept that contributed to micro-foundations between the years 2011-2020 was entrepreneurship (Dai et al., 2016; Helfat and Martin, 2015; Mahringer and Renzl, 2018; Nayak et al., 2019; Teece, 2012). The topics covered under this concept can be listed as entrepreneurial management, entrepreneurial orientation, entrepreneurial initiatives, intrapreneurship, corporate entrepreneurship and entrepreneurial fitness. 


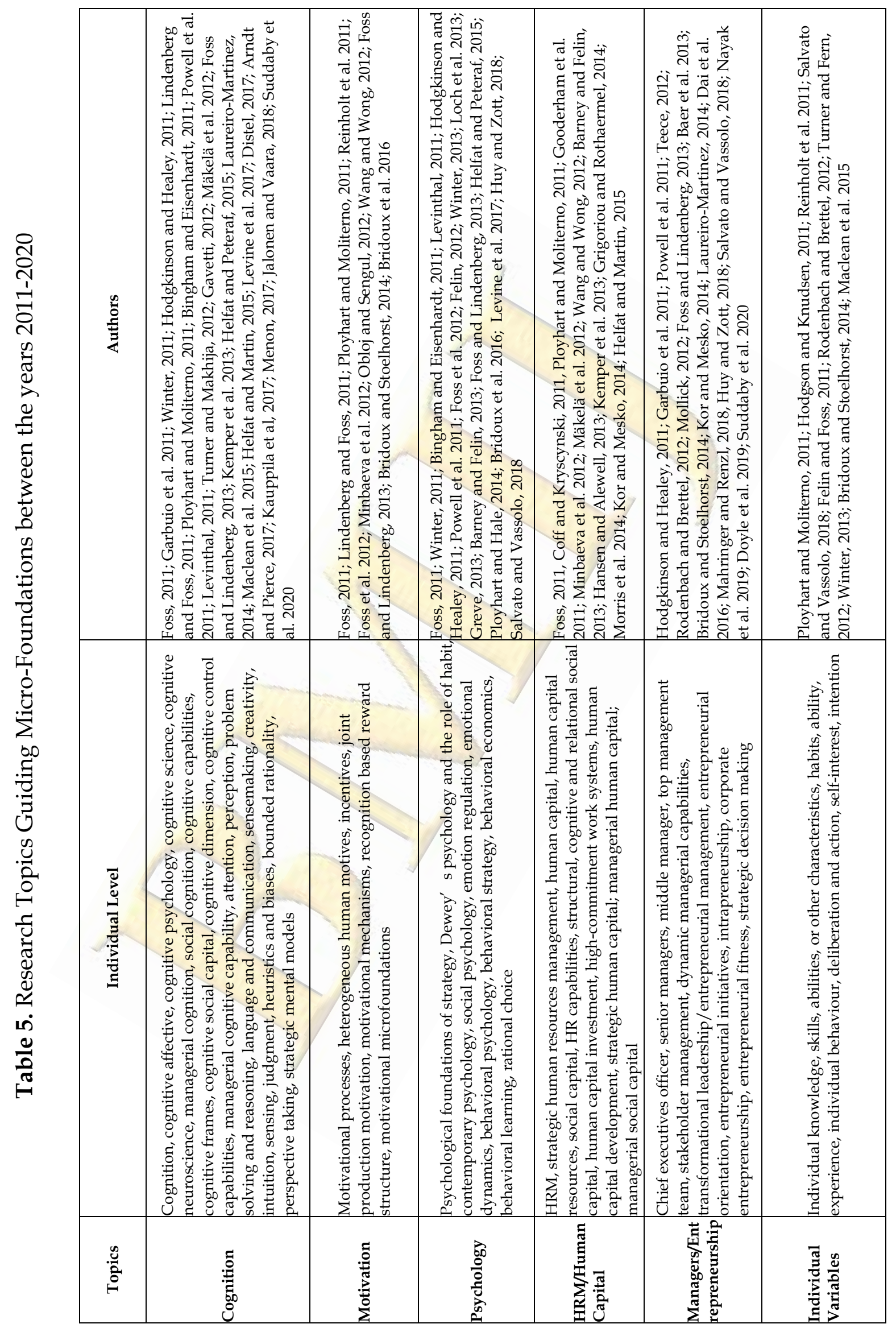


Continuation of table 5

\begin{tabular}{|c|c|c|c|c|c|c|}
\hline & 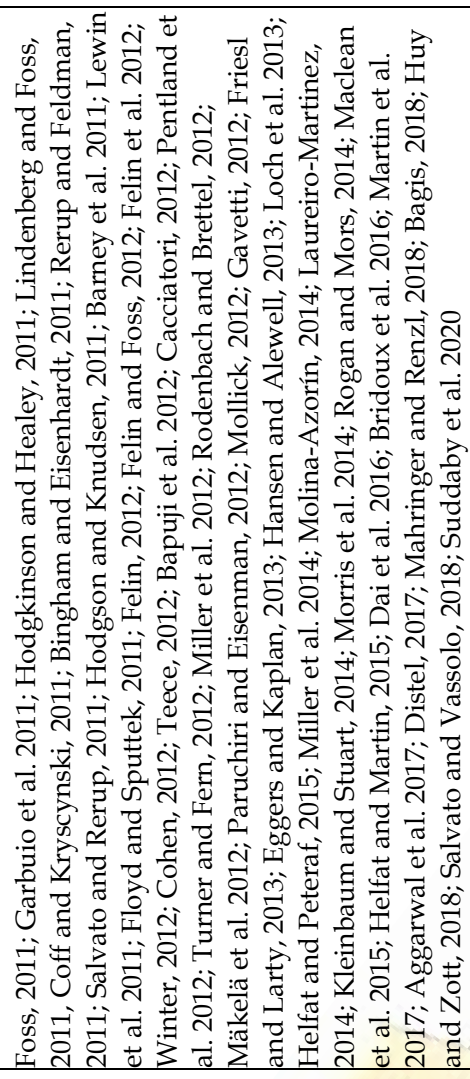 & 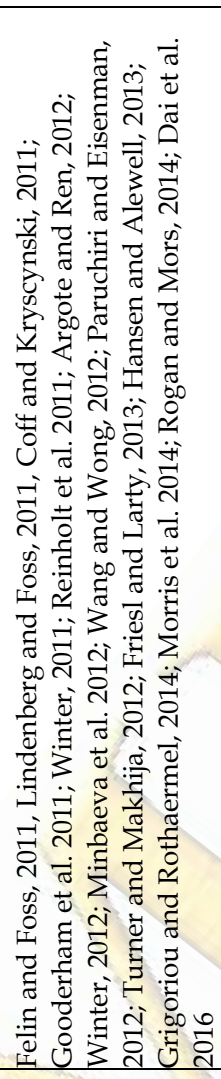 & 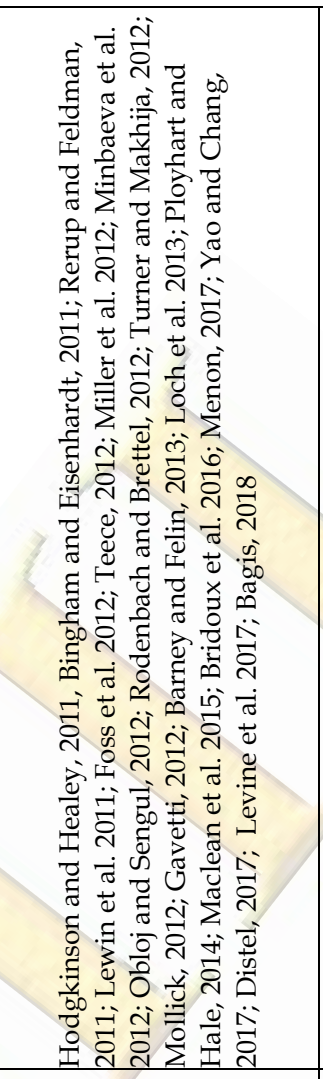 & 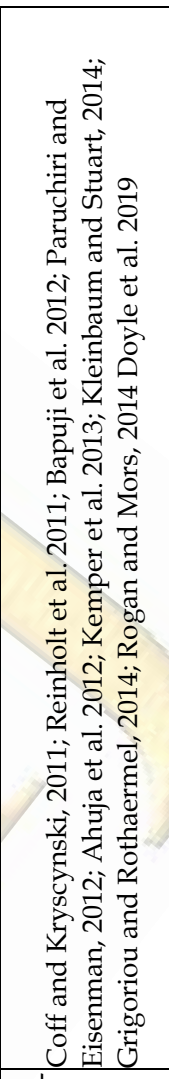 & 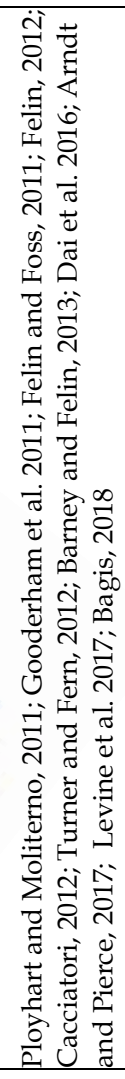 & 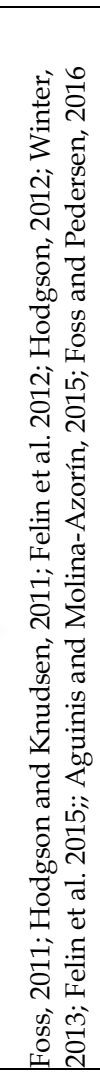 \\
\hline & 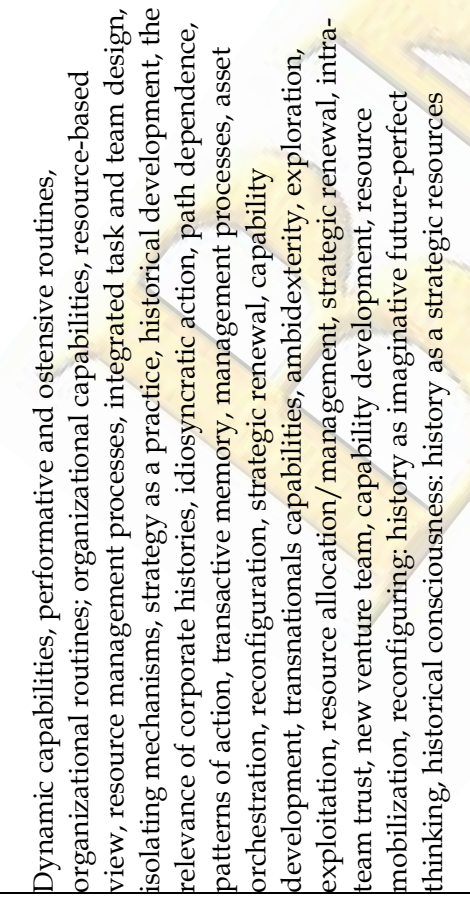 & 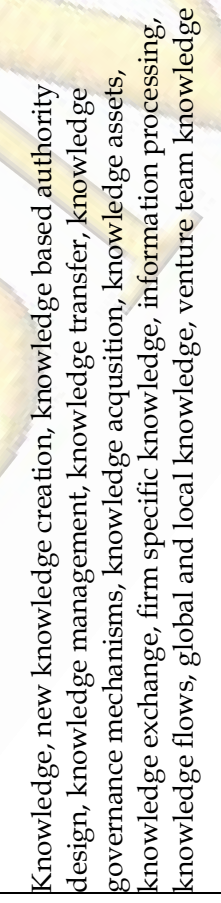 & 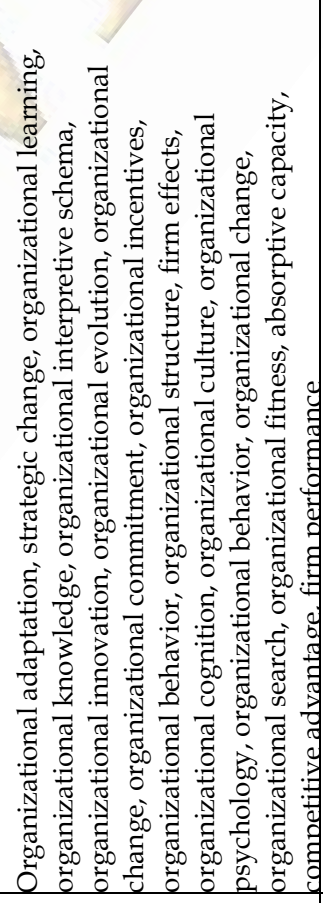 & 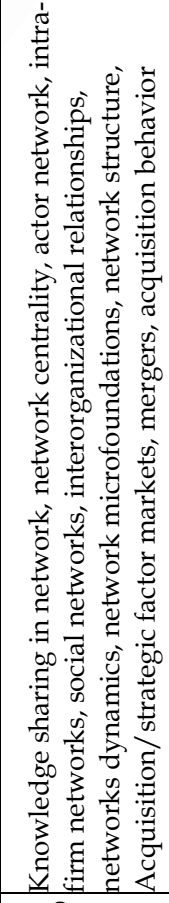 & 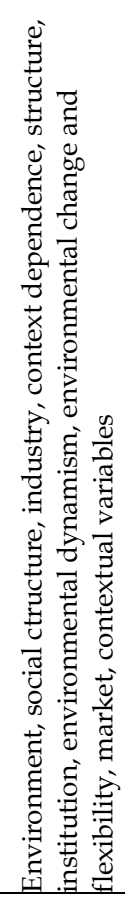 & 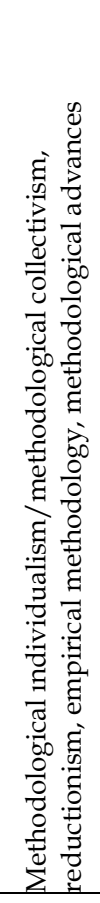 \\
\hline 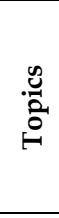 & 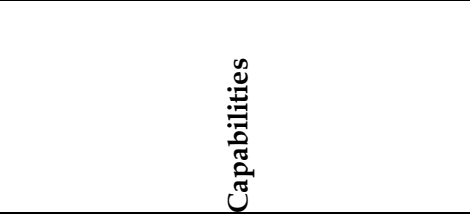 & & శ్ & 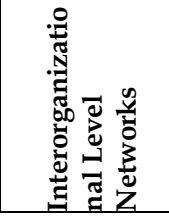 & & \\
\hline
\end{tabular}

Source: developed by the author 
The transfer of these concepts to the micro-foundations literature was due to the fact that dynamic capabilities studies were directly associated with entrepreneurship (Teece, 2007: 1346).

The fact that new fields of research on the phenomenon of capabilities emerged in the years between 2011-2020 compared to years between 2000-2010 was reflected in the findings in Table 5. It appears that the discipline of history began to be included in micro-foundations research especially with the concepts such as capability development (Gavetti, 2005: 601) historical development (Winter, 2012: 1404), the relevance of corporate histories (Teece, 2007: 1346), path dependence, history as imaginative future-perfect thinking, historical consciousness and history as a strategic resources (Suddaby et al., 2020: 3), history-informed strategy research (Argyres et al., 2020 ) in this period. Furthermore, it also appears that transactive memory (Argote and Ren, 2012: 1379; Dai et al., 2016: 3; Miller et al., 2012: 110) transnationals capabilities (Morris et al., 2014) based studies contributed to micro-foundations and that the concepts such as ambidexterity, exploration and exploitation were used more during this period compared to the years 2000-2010.

Another finding obtained from Table 5 indicates that research topics such as knowledge and knowledge management increased their effects compared to the years 2000-2010. The topics such as global and local knowledge (Morris et al., 2014) and venture team knowledge (Dai et al., 2016) began to be included in the studies on the micro-foundations of strategic management between the years 2011-2020. Another finding reveals that intra-firm networks (Paruchuri and Eisenman, 2012: 1509), in addition to interorganizational network studies, were used in micro-foundations studies.

The fact that macro-phenomena began to be discussed in the micro-foundations literature between the years 2011-2020 reveals the misperception that microfoundations research took only individual-level topics into consideration. Indeed, the phenomena such as environment, social structure, industry, context dependence, structure, institution, environmental dynamism, environmental change and flexibility, 
market and contextual variables in Table 5 support this situation. The studies that opened the micro-foundations literature for discussion (Barney and Felin, 2013: 144; Hodgson, 2012: 2-3; Jepperson and Meyer, 2011: 66) also supported this finding. Another finding obtained Table 5 is that the discussions on the micro-foundations of macro-phenomena such as acquisition, mergers and acquisition behavior (Coff and Kryscynski, 2011; Meyer-Doyle et al., 2019; Paruchuri and Eisenman, 2012) began between the years 2011-2020. Finally, methodological discussions in the microfoundations research between the years 2000-2010 also continued between the years 2011-2020 with the concepts of methodological individualism/methodological collectivism, reductionism, empirical methodology and methodological advances.

\section{CONCLUSION AND DISCUSSION}

In brief, this study examining the patterns of change in the micro-foundations of strategic management between the years 2000-2020 revealed the theories and research topics that contributed to the field of micro-foundations. The findings of the study indicated that there was an interdisciplinary expansion in the micro-foundations literature from 2000-2010 to 2011-2020. Multidisciplinary expansions give a view of both richness and fragmentation to strategic management in general and microfoundations literature in particular. While theoretical richness positively contributes to the explanation of strategic phenomena, it also leads to a serious methodology problem in the field (Aguinis and Molina-Azorín, 2015; Felin et al., 2012; Hodgson, 2012). Indeed, the findings in tables 4 and 5 under the topic of methodological individualism/methodological collectivism discussions also support the presence of this problem.

Although the field is mentioned by its micro-analysis levels, multidisciplinary expansions in the micro-foundations field reveal that the field should be evaluated together with the macro-strategic phenomena. Similarly, interdisciplinary expansions reveal the importance of intra-firm and out of-firm variables while performing evaluations on strategic phenomena in the field. These findings are consistent with Barney and Felin's (2013) claim that the field should not be mentioned only with the disciplines and fields such as psychology, human resources, or micro-organizational 
behavior, however, it should be evaluated together with macro-phenomena such as structure and institutions. In the study of Molina-Azorín (2014), the presence of a tendency to combine the studies at the macro and micro analysis levels related to strategic management in general and resource based view in particular is also supported by the findings in Table 4 and Table 5 .

Another issue that can be evaluated within the scope of the findings is that the micro-foundations of strategic management include the concepts and assumptions from different disciplines such as economics, sociology, psychology and history. This finding is compatible with the eclectic nature of strategic management (Barca, 2003). The findings in Table 3 indicated that the first studies on micro-foundations emerged with the economy-based game theory (Lippman and Rumelt, 2003a; 2003b). These findings indicated that the micro-foundations discussions in economics (Janssen, 1993) and sociology (Coleman, 1990) were moved to the strategic management field, and a new research trend was created in the field. Therefore, the concept of micro in microfoundations research should not just be reduced to the concept of bounded rationality in psychology and should be associated with the concepts of rational actor in economics and actor in sociology. From the findings in Table 3, it is seen that the concept of micro-foundations is associated with economics, sociology and psychology. This finding is consistent with the idea micro-foundations benefit from disciplines of economics, sociology and psychology, which was mentioned in the studies of Barney and Felin (2013) and Felin et al. (2015).

Finally, making some inferences from the findings and discussions so far regarding the fields to which the studies on the micro-foundations of strategic management can be directed will be useful for the course of future research. The findings in Table 3 indicated that micro-foundations research attempted to make new expansions towards history (Suddaby et al., 2020), evolutionary anthropology (Foss, 2011) and socio-evolutionary approach (Bridoux et al., 2016), adaptation-cost theory (Wernerfelt, 2020). Furthermore, the findings in Table 3 revealed that Austrian School Economics was used only in the study of Teece (2007). Austrian School Economics may help move the methodological individualism discussions more into the microfoundations discussions with the concepts of subjective psychology, subjective 
valuation, subjective experience, subjective life, subjective meaning and subjective values (Udehn, 2013). Similarly, the transfer of psychology-based regulative focus theory into the micro-foundations field remained at the level of senior managers in the capabilities research (Tunçdoğan, 2014). A review on the regulatory focus of operational managers and employees may produce significant results regarding the micro-foundations of capabilities.

In conclusion, there is an efficient field regarding the transfer of discussions on the micro-foundations of political and economic institutions to the micro-foundations of strategic management. In particular, inclusive or exploitative political and economic institutions (Acemoglu and Robinson, 2012) positively or negatively affect the creative destructive activities of senior managers (Schumpeter, 2003: 83). Therefore, the effects of inclusive and exploitative economic institutions on managers and employees, and the reflections of this situation on firm performance and capabilities can be discussed in the studies, so that it will be possible to enable micro-foundations research to make new expansions. 


\section{REFERENCES}

Abell, P., Felin, T., and Foss, N. (2008). Building micro-foundations for the routines, capabilities, and performance links. Managerial and Decision Economics, 29(6), 489-502.

Acemoglu, D., and Robinson, J. A. (2012). Why nations fail: The origins of power, prosperity, and poverty: Crown Books.

Adner, R., and Helfat, C. E. (2003). Corporate effects and dynamic managerial capabilities. Strategic Management Journal, 24(10), 1011-1025.

Aguinis, H., and Molina-Azorín, J. F. (2015). Using multilevel modeling and mixed methods to make theoretical progress in microfoundations for strategy research. Strategic Organization, 13(4), 353-364.

Argyres, N. S., De Massis, A., Foss, N. J., Frattini, F., Jones, G., and Silverman, B. S. (2020). Historyinformed strategy research: The promise of history and historical research methods in advancing strategy scholarship. Strategic Management Journal, 41(3), 343-368.

Argote, L., and Ren, Y. (2012). Transactive memory systems: A microfoundation of dynamic capabilities. Journal of Management Studies, 49(8), 1375-1382.

Bağış, M. (2018). Dinamik yeteneklerin mikro temelleri olarak etkileşimsel yaratıcılık yaklaşımı. İşletme Araştırmaları Dergisi, 10(4), 1163-1185.

Bağış, M., and Hızıroğlu, M. (2018). Stratejik Yönetim' in Kaynaklara Dayalı Yaklaşımı: Ekonomik, Sosyolojik, Psikolojik Temeller. Ankara: Nobel Akademik Yayıncılık, Nobel Bilimsel Eserler.

Bağış, M., Karagüzel, E. S., Kryeziu, L., and Ardıç, K. (2019). A Longitudinal analysis on intellectual structure of human resources management: Theoretical foundations and research trends. Mehmet Akif Ersoy Üniversitesi İktisadi ve İdari Bilimler Fakültesi Dergisi, 6(3), 796-814.

Barca, M. (2003). Economic foundations of strategic management. England: Ashgate Publishing Limited.

Barney, J. (1991). Firm resources and sustained competitive advantage. Journal of Management, 17(1), 99120.

Barney, J., and Felin, T. (2013). What are microfoundations? The Academy of Management Perspectives, 27(2), 138-155.

Barney, J. B. (1991). Firm resources and sustained competitive advantage. Journal of Management, 17(1), 99-120.

Barney, J. B., Ketchen, D. J., and Wright, M. (2011). The future of resource-based theory revitalization or decline? Journal of Management, 37(5), 1299-1315.

Becker, G. S. (1964). Human Capital: A Theoretical and Empirical Analysis, with Special Reference to Education, by Gary S. Becker: London.

Bowen, G. A. (2009). Document analysis as a qualitative research method. Qualitative Research Journal, 9(2), 27-40.

Bridoux, F., Coeurderoy, R., and Durand, R. (2017). Heterogeneous social motives and interactions: The three predictable paths of capability development. Strategic Management Journal, 38(9), 1755-1773.

Coff, R. W. (1997). Human assets and management dilemmas: Coping with hazards on the road to resource-based theory. Academy of Management Review, 22(2), 374-402.

Coff, R. W. (1999). When competitive advantage doesn't lead to performance: The resource-based view and stakeholder bargaining power. Organization Science, 10(2), 119-133.

Coff, R., and Kryscynski, D. (2011). Invited editorial: Drilling for micro-foundations of human capitalbased competitive advantages. Journal of Management, 37(5), 1429-1443.

Coleman, J. (1990). Foundations of social theory. Cambridge: MA: Belknap. 
Crossan, M. M., Lane, H. W., White, R. E., and Djurfeldt, L. (1995). Organizational learning: Dimensions for a theory. The International Journal of Organizational Analysis, 3(4), 337-360.

Cyert, R. M., and March, J. G. (1963). A behavioral theory of the firm. Englewood Cliffs, NJ, 2.

Dai, Y., Roundy, P. T., Chok, J. I., Ding, F., and Byun, G. (2016). ‘Who Knows What?' in New Venture Teams: Transactive Memory Systems as a Micro-Foundation of Entrepreneurial Orientation. Journal of Management Studies, 53(8), 1320-1347.

De Wit, B., and Meyer, R. (2010). Strategy: process, content, context: an international perspective: Cengage Learning EMEA.

Dyer, J. H., and Singh, H. (1998). The relational view: Cooperative strategy and sources of interorganizational competitive advantage. Academy of Management Review, 23(4), 660-679.

Felin, T., and Foss, N. J. (2005). Strategic organization: A field in search of micro-foundations. Strategic Organization, 3(4), 441-455

Felin, T., Foss, N. J., Heimeriks, K. H., and Madsen, T. L. (2012). Microfoundations of routines and capabilities: Individuals, processes, and structure. Journal of Management Studies, 49(8), 1351-1374.

Felin, T., Foss, N. J., and Ployhart, R. E. (2015). The microfoundations movement in strategy and organization theory. The academy of Management Annals, 9(1), 575-632.

Finkelstein, S., Hambrick, D., and Cannella, A. A. (1996). Strategic leadership. St. Paul: West Educational Publishing.

Flick, U. (2018). An introduction to qualitative research: Sage Publications Limited.

Foss, K., and Foss, N. J. (2005). Resources and transaction costs: How property rights economics furthers the resource-based view. Strategic Management Journal, 26(6), 541-553.

Foss, N. J. (2003). Bounded rationality and tacit knowledge in the organizational capabilities approach: an assessment and a re-evaluation. Industrial and Corporate Change, 12(2), 185-201.

Foss, N. J. (2005). Scientific Progress in Strategic Management: The case of the Resource-based view. Available at SSRN 982089.

Foss, N. J. (2011). Invited editorial: Why micro-foundations for resource-based theory are needed and what they may look like. Journal of Management, 37(5), 1413-1428.

Foss, N. J., and Lindenberg, S. (2013). Microfoundations for strategy: A goal-framing perspective on the drivers of value creation. The Academy of Management Perspectives, 27(2), 85-102.

Foss, N. J., and Linder, S. (2019). Microfoundations: nature, debate, and promise (Kindle Edition ed.): Cambridge University Press.

Gavetti, G. (2005). Cognition and hierarchy: Rethinking the microfoundations of capabilities' development. Organization Science, 16(6), 599-617.

Grant, R. M. (1996a). Prospering in dynamically-competitive environments: Organizational capability as knowledge integration. Organization Science, 7(4), 375-387.

Grant, R. M. (1996b). Toward a knowledge-based theory of the firm. Strategic Management Journal, 17(S2), 109-122.

Hambrick, D. C., and Mason, P. A. (1984). Upper echelons: The organization as a reflection of its top managers. Academy of Management Review, 9(2), 193-206.

Helfat, C. E., and Martin, J. A. (2015). Dynamic managerial capabilities: Review and assessment of managerial impact on strategic change. Journal of Management, 41(5), 1281-1312.

Helfat, C. E., and Peteraf, M. A. (2015). Managerial cognitive capabilities and the microfoundations of dynamic capabilities. Strategic Management Journal, 36(6), 831-850.

Hodgkinson, G. P., and Healey, M. P. (2011). Psychological foundations of dynamic capabilities: reflexion and reflection in strategic management. Strategic Management Journal, 32(13), 1500-1516. 
Hodgson, G. M. (2012). The mirage of microfoundations. Journal of Management Studies, 49(8), 1389-1394. Janssen, M. C. (1993). Microfoundations: a critical inquiry. London and New York: Routledge.

Jepperson, R., and Meyer, J. W. (2011). Multiple levels of analysis and the limitations of methodological individualisms. Sociological Theory, 29(1), 54-73.

Kahneman, D., and Tversky, A. (1979). Prospect theory: An analysis of decision under risk. Econometrica: journal of the Econometric Society, 47(2), 263-291.

Kahneman, D., Slovic, S. P., Slovic, P., and Tversky, A. (Eds.). (1982). Judgment under uncertainty: Heuristics and biases. Cambridge university press.

Kogut, B., and Zander, U. (1992). Knowledge of the firm, combinative capabilities, and the replication of technology. Organization Science, 3(3), 383-397.

Lavie, D. (2006). The competitive advantage of interconnected firms: An extension of the resource-based view. Academy of Management Review, 31(3), 638-658.

Lindenberg, S., and Foss, N. J. (2011). Managing joint production motivation: The role of goal framing and governance mechanisms. Academy of Management Review, 36(3), 500-525.

Lippman, S. A., and Rumelt, R. P. (2003a). A bargaining perspective on resource advantage. Strategic Management Journal, 24(11), 1069-1086.

Lippman, S. A., and Rumelt, R. P. (2003b). The payments perspective: micro-foundations of resource analysis. Strategic Management Journal, 24(10), 903-927.

Locke, E. A., and Latham, G. P. (2012). Goal setting theory Motivation: Theory and research (pp. 23-40): Routledge.

Mahringer, C. A., and Renzl, B. (2018). Entrepreneurial initiatives as a microfoundation of dynamic capabilities. Journal of Accounting and Organizational Change, 14(1), 61-79.

Meyer-Doyle, P., Lee, S., and Helfat, C. E. (2019). Disentangling the microfoundations of acquisition behavior and performance. Strategic Management Journal, 40(11), 1733-1756.

Miles, M. B., Huberman, A. M. (1994). Qualitative data analysis: An expanded sourcebook: sage. Thousand oaks CA Sage.

Miller, K. D., Pentland, B. T., and Choi, S. (2012). Dynamics of performing and remembering organizational routines. Journal of Management Studies, 49(8), 1536-1558.

Molina-Azorín, J. F. (2014). Microfoundations of strategic management: Toward micro-macro research in the resource-based theory. BRQ Business Research Quarterly, 17(2), 102-114.

Morris, S., Hammond, R., and Snell, S. (2014). A microfoundations approach to transnational capabilities: The role of knowledge search in an ever-changing world. Journal of International Business Studies, 45(4), 405-427.

Nayak, A., Chia, R., and Canales, J. I. (2019). Non-cognitive microfoundations: understanding dynamic capabilities as idiosyncratically refined sensitivities and predispositions. Academy of Management Review(in press).

Nelson, R. R., and Winter, S. G. (1982). An evolutionary theory of economic change. Harvard University, Cambridge, Massachusetts and London, England: The Belknap Press

Ocasio, W. (1997). Towards an attention based view of the firm. Strategic Management Journal, 18(Summer Special Issue), 187-206.

Paruchuri, S., and Eisenman, M. (2012). Microfoundations of firm R\&D capabilities: A study of inventor networks in a merger. Journal of Management Studies, 49(8), 1509-1535.

Peng, M. W. (2002). Towards an institution-based view of business strategy. Asia Pacific Journal of Management, 19(2-3), 251-267. 
Peng, M. W., Sun, S. L., Pinkham, B., and Chen, H. (2009). The Institution-Based View as a Third Leg for a Strategy Tripod. The Academy of Management Perspectives, 23(3), 63-81.

Porter, M. E. (1980). Competitive startegy: Technigues for analyzing industies and competitors. New York: Free Press.

Porter, M. E. (1981). The contributions of industrial organization to strategic management. Academy of Management Review, 6(4), 609-620.

Powell, T. C., Lovallo, D., and Fox, C. R. (2011). Behavioral strategy. Strategic Management Journal, 32(13), 1369-1386.

Pozzebon, M. (2004). The influence of a structurationist view on strategic management research. Journal of Management Studies, 41(2), 247-272.

Raghuram, S., Tuertscher, P., and Garud, R. (2010). Research note-mapping the field of virtual work: A cocitation analysis. Information Systems Research, 21(4), 983-999.

Thaler, R. H., and Sunstein, C. R. (2009). Nudge: Improving decisions about health, wealth, and happiness. Penguin.

Schreier, M. (2012). Qualitative content analysis in practice: Sage publications.

Schumpeter, J. A. (2003). Capitalism, Socialism and Democracy. London and New York: Taylor and Francis e-Library.

Simon, H. A. (1947). Administrative behavior. A study of decision-making processes in administrative organization (Fourth Edition ed.): The Free Press, New York.

Strauss, A. L. (1987). Qualitative analysis for social scientists: Cambridge university press.

Suddaby, R., Coraiola, D., Harvey, C., and Foster, W. (2020). History and the micro-foundations of dynamic capabilities. Strategic Management Journal, 41(3), 530-556.

Teece, D., and Pisano, G. (1994). The dynamic capabilities of firms: an introduction. Industrial and Corporate Change, 3(3), 537-556.

Teece, D. J. (2007). Explicating dynamic capabilities: the nature and microfoundations of (sustainable) enterprise performance. Strategic Management Journal, 28(13), 1319-1350.

Teece, D. J. (2012). Dynamic capabilities: Routines versus entrepreneurial action. Journal of Management Studies, 49(8), 1395-1401.

Teece, D. J., Pisano, G., and Shuen, A. (1997). Dynamic capabilities and strategic management. Strategic Management Journal, 18(7), 509-533.

Tunçdoğan I.., A. (2014). Decision Making and Behavioral Strategy: The Role of Regulatory Focus in Corporate Innovation Processes. Erasmus University, Rotterdam.

Udehn, L. (2013). Methodological individualism: Oxford University Press.

Usdiken, B., and Wasti, S. A. (2002). Türkiye'de akademik bir inceleme alanı olarak personel veya" insan kaynakları" yönetimi, 1972-1999. Amme İdaresi Dergisi, 35(3), 1-37.

Wernerfelt, B. (2020). A possible micro-foundation for the RBV and its implications. Strategic Management Review, 1(1), 145-158.

Whittington, R. (1996). Strategy as practice. Long Range Planning, 29(5), 731-735.

Winter, S. G. (2012). Capabilities: Their origins and ancestry. Journal of Management Studies, 49(8), 14021406.

Zupic, I., and Čater, T. (2015). Bibliometric methods in management and organization. Organizational Research Methods, 18(3), 429-472. 